\title{
PENGEMBANGAN INSTRUMEN TES PILIHAN GANDA UNTUK MENGIDENTIFIKASI KARAKTERISTIK KONSEP TERMODINAMIKA MAHASISWA PRODI PENDIDIKAN FISIKA UNIVERSITAS KANJURUHAN MALANG
}

\author{
Hestiningtyas Yuli Pratiwi \\ Prodi Pendidikan Fisika Universitas Kanjuruhan Malang \\ hestiphysics@,gmail.com
}

Telah dilakukan penelitian yang bertujuan mengembangkan instrumen penilaian sebagai upaya untuk mengidentifikasi karakteristik konsep Termodinamika mahasiswa Prodi Pendidikan Fisika Universitas Kanjuruhan Malang. Instrument penilaian yang dikembangkan adalah tes pilihan ganda. Prosedur penelitian mengikuti langkah-langkah pengembangan yang dilakukan oleh Borg and Gall. Langkah tersebut telah diadopsi dan dimodifikasi oleh Sukmadinata. Pengumpulan data dilakukan melalui angket, wawancara, tes uraian, dan tes pilihan ganda distraktor bermakna. Berdasarkan data angket validasi oleh ahli, diketahui bahwa instrumen tes yang dikembangkan dinyatakan layak dalam ranah materi, konstruksi, dan bahasa. Data dianalisis untuk mengidentifikasi karakteristik konsepsi, analisis dilakukan meliputi: analisis tiap indikator soal, analisis level tiap butir soal, analisis profil peserta didik, dan analisis profil kelas. Secara keseluruhan, analisis profil kelas menunjukkan bahwa mahasiswa yang memahami konsep dengan benar masih tergolong rendah, yaitu 29,68 \%, sedangkan $70,32 \%$ mengalami miskonsepsi.

Kata kunci: instrumen, pilihan ganda, distraktor, konseps, gas ideal

Has conducted research aimed at developing assessment instruments in an attempt to identify the characteristics of the concept of Thermodynamics students Physical Education Kanjuruhan University of Malang. Assessment instrument developed is a multiple choice test. Research procedures follow the development steps undertaken by the Borg and Gall. The move has been adopted and modified by Sukmadinata. Data collected through questionnaires, interviews, test description, and multiple-choice tests distractors meaningful. Based on questionnaire odata validation by experts, it is known that the test instrument was developed as feasible in the realm of material, construction, and language. Data were analyzed to identify the characteristics of conception, analysis carried out by analysis of each indicator question, each level of analysis items, analysis of learner profiles, and profile analysis of class. Overall, the class profile analyzes showed that students understand the concept correctly is still relatively low, at $29.68 \%$, while $70.32 \%$ had misconceptions.

Keywords: instrument, multiple choice, distractors, concept, ideal gas

\section{PENDAHULUAN}

Asesmen pada dasarnya merupakan serangkaian kegiatan yang dilakukan oleh pendidik dan dimaksudkan untuk membantu atau mendampingi peserta didik belajar (Beverley \& Education, 2002). Asesmen juga berarti merupakan proses memandu Peserta didik mencapai kompetensi yang diharapkan (Rusilowati \& Sopyan, 2011). Jika ada Peserta didik yang mengalami masalah, pendidik perlu membantunya untuk mencapai keberhasilan belajar (Kusari., 2014). Asesmen tentunya juga memberi informasi pada peserta didik tentang kemajuan belajar, tidak hanya sekedar tes untuk menentukan 
kelulusan peserta didik tetapi merupakan satu kesatuan penting dalam pembelajaran (Wijaya., 2013). Dalam Peraturan Menteri pendidikan dan Kebudayaan Nomor 54 Tahun 2013 dinyatakan bahwa Standar Kompetensi Lulusan adalah kriteria mengenai kualifikasi kemampuan lulusan yang mencakup sikap, pengetahuan, dan keterampilan. Peserta didik diharuskan menguasai konsep dan mampu mengintegrasikan pengetahuan dalam kehidupan sehari-hari (Permendikbud, 2013). Konsep merupakan abstraksi dari ciri-ciri sesuatu yang mempermudah komunikasi antara manusia dan yang memungkinkan manusia berpikir (Nline et al. 2008; Rusilowati \& Sopyan 2011). Umumnya, konsep mempunyai tingkatan (jenjang) dan saling berhubungan antar konsep yang satu dengan lainnya, sehingga konsep sederhana menunjang pemahaman terhadap konsep yang lebih kompleks (Ibrahim, 2012; Berg, dkk., 1991).

Implementasi proses pembelajaran fisika seringkali mengalami kesalahan dalam memahami konsep (miskonsepsi) (Bilgin, 2009; Nottis et al. 2010; Donnelly, Christina, 2014). Kesalahan yang terjadi dalam memahami konsep diindikasikan oleh adanya perbedaan konsep yang diterima peserta didik terhadap suatu konsep yang disepakati dan dianggap benar oleh para ahli. Pemahaman yang demikian akan semakin parah ketika menganggap proses belajar adalah transfer ilmu dari pengajar ke peserta didik, padahal peserta didik sudah memiliki pengetahuan awal yang membentuk konsepnya ketika mereka menempuh studi di sekolah menengah Teridentifikasinya konsepsi peserta didik terhadap suatu materi, maka pembelajaran yang berlangsung dapat menjadi lebih bermakna dan mampu digunakan untuk mengatasi kesulitan belajar (Kang et al. 2010).

Identifikasi dengan menggunakan tes diagnostik berbentuk pilihan ganda yang terdiri dari tiga alternatif jawaban dan disertai alasan mampu menunjukkan adanya karakteristik pemahaman konsep pada peserta didik (Nottis, Prince, and Vigeant 2010). Tes diagnostik digunakan untuk mengetahui kelemahan-kelemahan peserta didik sehingga dapat dilakukan pemberian perlakuan yang tepat (Wells, 1994; Arikunto, 2009). Sejalan dengan apa yang disampaikan oleh Wijaya (2013) bahwa penelusuran kesulitan belajar dalam menguasai materi pembelajaran dapat menggunakan tes diagnostik. Hal ini menunjukkan bahwa tes diagnostik sengaja dirancang sebagai alat untuk menemukan kesulitan belajar yang dihadapi peserta didik. Hasil tes diagnostik dapat digunakan sebagai dasar penyelenggaraan pengajaran yang lebih sesuai dengan kemampuan peserta didik sebenarnya termasuk kesulitan belajarnya (Donnelly, Christina, 2014; Kácovský 2013;Stedman \& Adams 2012; Tanahoung et al. 2010; Taylor et al. 2002).

Studi pendahuluan terhadap subyek penelitian, mahasiswa prodi pendidikan fisika Unikama, diketahui bahwa sebesar $66,67 \%$ tidak memahami konsep Gas Ideal. Oleh karena itu, sebagai langkah awal perlu dilakukan upaya untuk mengidentifikasi karakteristik pemahaman konsep termodinamika mahasiswa dan memberi umpan balik mahasiswa. Salah satu upaya yang 
diberikan adalah pemberian tes diagnostik berupa soal pilihan ganda distraktor bermakna

\section{METODE}

Tahapan penelitian yang dilakukan dari hasil adaptasi dan modifikasi model Gall dan Borg adalah 1) Melakukan studi pendahuluan, yaitu melakukan studi pustaka dan studi lapang; 2) Merancang draf instrumen (Creswell 2010). Langkah yang dilakukan adalah mengumpulkan bentuk-bentuk miskonsepsi pada materi Gas Ideal, menyusun indikator, menyusun butir soal uraian, memvalidasi soal uraian, dan melakukan uji coba soal uraian; Mengembangkan draf instrumen (Richey, Klein, and Nelson 2011). Tahap ini adalah menganalisis jawaban peserta didik dari soal uraian, menyusun butir soal pilihan ganda, memvalidasi tes pilihan ganda distraktor bermakna, dan melakukan revisi; 4) Melakukan uji coba terbatas. Setelah tes pilihan ganda distraktor bermakna direvisi, maka dilakukan uji coba terbatas di offering C angkatan 2012 mahasiswa Prodi Pendidikan Fisika Unikama; dan 5) Merevisi produk hasil pengembangan.

Hasil pengembangan pada tahap ini berupa berupa instrumen dengan materi Gas Ideal dalam bentuk tes pilihan ganda distraktor bermakna. Produk tersebut bertujuan untuk mengidentifikasi karakteristik konsep mahasiswa. Alternatif pilihan jawaban dikembangkan berdasarkan deskripsi level yang diperoleh dari jawaban peserta didik pada tes uraian (Melissa S. Anderson, et. all. 2013). Masing-masing indikator dikembangkan menjadi tiga butir soal yang setara dan sama agar dapat mengetahui konsistensi jawaban responden.

Uji coba pada penelitian adalah uji coba kelompok kecil (uji coba terbatas). Uji coba kelompok kecil merupakan uji coba terbatas. Hasil uji coba digunakan untuk menganalisis butir soal dan menganalisis karakteristik konsepsi. Pengumpulan data dilakukan melalui wawancara, angket, tes uraian, dan tes pilihan ganda distraktor bermakna. Hasil wawancara digunakan untuk mendukung perlunya mengangkat permasalahan. Data dari angket digunakan untuk mengevaluasi produk instrumen yang dihasilkan. Angket yang digunakan menggunakan penilaian skala Likert dengan nilai 1 sampai 4 .

Data uji coba terbatas tes pilihan ganda distraktor bermakna diperoleh dari jawaban peserta didik. Data ini digunakan untuk menganalisis butir soal dan mengidentifikasi karakteristik konsepsi peserta didik. Analisis butir soal yang dilakukan meliputi: validitas, reliabilitas, tingkat kesukaran, daya pembeda, dan kualitas pengecoh.

\section{Analisis Deskriptif}

Hasil angket validasi dianalisis menggunakan perhitungan rata-rata dengan mengacu pada kriteria yang digunakan untuk mengukur tingkat kelayakan yang diberikan oleh Sugiyono (Sugiyono, 2010). Analisa terhadap data angket validasi meliputi materi, konstruksi, dan bahasa. Dari soal yang dikembangkan diketahui bahwa sebagian butir soal dinyatakan valid oleh tim ahli, dan ada beberapa butir soal $(4,5,6)$ disarankan ada perbaikan pada ranah konstruksi dan bahasa. 
Setelah instrument tes pilihan ganda diujicoba, maka setiap butir soal dianalisis melalui validitas butir soal, reliabilitas, tingkat kesukaran, daya pembeda, dan kualitas pengecoh. Untuk validitas butir soal dihitung menggunakan rumus korelasi point biserial menurut Arikunto (Arikunto, 2009:78). Hasil validitas butir soal menunjukkan bahwa didapat 16 butir soal yang valid. Hal ini diketahui karena hasil uji diperoleh nilai $r_{(21 ; 0.05)}$ adalah 0,433. Pada pengembangan ini, butir soal yang dinyatakan tidak valid tetap digunakan, karena butir soal tersebut sebetulnya dinyatakan layak oleh tim ahli dan dapat mendeteksi konsepsi peserta didik. Namun, perlu diperbaiki struktur kalimat dan bahasa.

Hasil uji reliabilitas untuk 16 butir soal berdasarkan Kuder dan Richardson (Arikunto, 2009) adalah valid sebab memiliki tingkat reliabilitas sangat tinggi, sebesar 0,931. Hasil ini memberi kesimpulan bahwa alat ukur yang dikembangkan dapat memberikan gambaran yang benar-benar dapat dipercaya tentang kemampuan seseorang. Untuk proporsi peserta didik yang menjawab benar atau salah, berdasarkan persamaan yang dikemukan Arikunto (2009) memberikan hasil bahwa dari 30 butir soal yang dibuat sebanyak 18 butir soal kategori sukar, 10 butir soal kategori sedang, dan 2 butir soal kategori mudah.

Daya beda soal dihitung menggunakan persamaan Arikunto (2009), diantara 30 soal yang diberikan; termasuk dalam kategori sangat baik sejumlah 1 butir soal, kategori baik sejumlah 2 butir soal, kategori cukup baik sejumlah 11 butir soal, kategori jelek sejumlah 13 butir soal, dan kategori tidak baik sejumlah 3 butir soal. Daya pembeda dalam kategori jelek dan tidak baik menyebabkan jawaban peserta didik dapat dilakukan dengan cara menebak. Akan tetapi, hal ini sudah ditangani dengan mengembangkan satu indikator menjadi 3 butir soal yang setara dan sama, sehingga peserta didik yang menjawab menebak dapat diketahui dengan pasti. Dalam segi kualitas pengecoh, dapat diketahui bahwa sebagian besar butir soal sudah memiliki pengecoh baik.

\section{Analisis Identifikasi Karakteristik Konsep}

Analisis identifikasi karakteristik konsepsi peserta didik meliputi: analisis tiap indikator, analisis profil peserta didik, analisis level butir soal, dan analisis profil kelas. Untuk mempermudah analisis peneliti menggunakan program AAFF (Analisis Asesmen Formatif Fisika). Penggunaan software Microsoft Excel, analisis tiap indikator menghasilkan diagram yang menunjukkan persentase jawaban reponden untuk level 1, 2, 3, 4, dan Non Consistence (NC). Analisis ini digunakan untuk menunjukkan bahwa mahasiswa memahami atau tidak terhadap konsep sehingga dalam menjawab soal kemungkinan dengan cara menebak.

Analisis level butir soal dimaksudkan untuk mengetahui analisis respon seluruh mahasiswa terhadap butir soal tertentu. Hasil analisis level butir soal berupa grafik yang menggambarkan persentase jawaban tiap level dalam setiap butir soal. Perhitungan menggunakan rumus sebagai berikut. 


$$
P=\frac{\sum x_{i}}{\sum x_{n}} \times 100 \%
$$

Keterangan:

$\mathrm{P}=$ persentase level pada butir tertentu

$\sum x_{i}=$ jumlah mahasiswa yang menjawab

level tertentu pada tiap butir tertentu

$\sum x_{n}=$ jumlah mahasiswa keseluruhan

\section{Analisis Profil Kelas}

Analisis profil kelas menunjukkan gambaran pencapaian seluruh mahasiswa pada tes yang telah dilaksanankan. Hasil analisis profil kelas berupa grafik yang menggambarkan persentase jawaban yang diberikan oleh seluruh mahasiswa pada setiap level untuk semua butir soal. Perhitungan menggunakan rumus sebagai berikut.

$$
P=\frac{\sum x_{i}}{\sum x_{n}} \times 100 \%
$$

Keterangan:

$\mathrm{P}=$ persentase level untuk semua butir soal oleh seluruh mahasiswa

$\sum x_{i}=$ jumlah seluruh mahasiswa yang menjawab level tertentu untuk semua butir soal

$\sum x_{n}=$ jumlah seluruh mahasiswa $\mathrm{x}$ jumlah semua butir soal

\section{HASIL DAN PEMBAHASAN}

Hasil analisis data angket validasi meliputi ranah materi, konstruksi, dan bahasa, sebagian butir soal dinyatakan valid oleh tim ahli. Hanya butir soal nomor 4, 5, 6 yang dinyatakan cukup layak untuk ranah konstruksi dan bahasa. Setelah instrumen tes pilihan ganda distraktor bermakna diujicobakan pada 21 mahasiswa, setiap butir soal dianalisis melalui validitas butir soal, reliabilitas, tingkat kesukaran, daya pembeda, dan kualitas pengecoh. Hasil validitas butir soal telah diperoleh 16 butir soal yang valid, diuji dengan nilai $\mathrm{r}_{(21 ; 0.05)}$ adalah 0,433. Butir soal yang dinyatakan tidak valid, tetap digunakan, karena butir soal tersebut sebetulnya telah dinyatakan layak oleh tim ahli dan dapat mendeteksi konsepsi mahasiswa. Hanya saja, butir soal tersebut perlu diperbaiki struktur kalimat dan bahasa sesuai saran tim ahli.

Hasil uji reliabilitas untuk 16 butir soal valid dari instrumen tes pilihan ganda distraktor bermakna memiliki tingkat reliabilitas sangat tinggi, sebesar 0,931. Hasil uji tingkat kesukaran, diketahui bahwa untuk kategori sukar sejumlah 18 butir soal, kategori sedang sejumlah 10 butir soal, dan kategori mudah sejumlah 2 butir soal. Untuk daya pembeda termasuk dalam kategori sangat baik sejumlah 1 butir soal, kategori baik sejumlah 2 butir soal, kategori cukup baik sejumlah 11 butir soal, kategori jelek sejumlah 13 butir soal, dan kategori tidak baik sejumlah 3 butir soal. Daya pembeda dalam kategori jelek dan tidak baik menyebabkan jawaban mahasiswa dapat dilakukan dengan cara menebak. Akan tetapi, hal ini sudah ditangani dengan mengembangkan satu indikator menjadi 3 butir soal yang setara dan sama, sehingga mahasiswa yang menjawab menebak dapat diketahui dengan pasti. Dalam segi kualitas pengecoh, dapat diketahui bahwa sebagian besar butir soal sudah memiliki pengecoh baik.

Analisis tiap indikator menghasilkan diagram yang menunjukkan persentase jawaban reponden untuk level 1, 2, 3, 4, dan Non Consistence (NC). Gambar 
1 berikut menunjukkan hasil analisis tiap indikator untuk indikator 1.

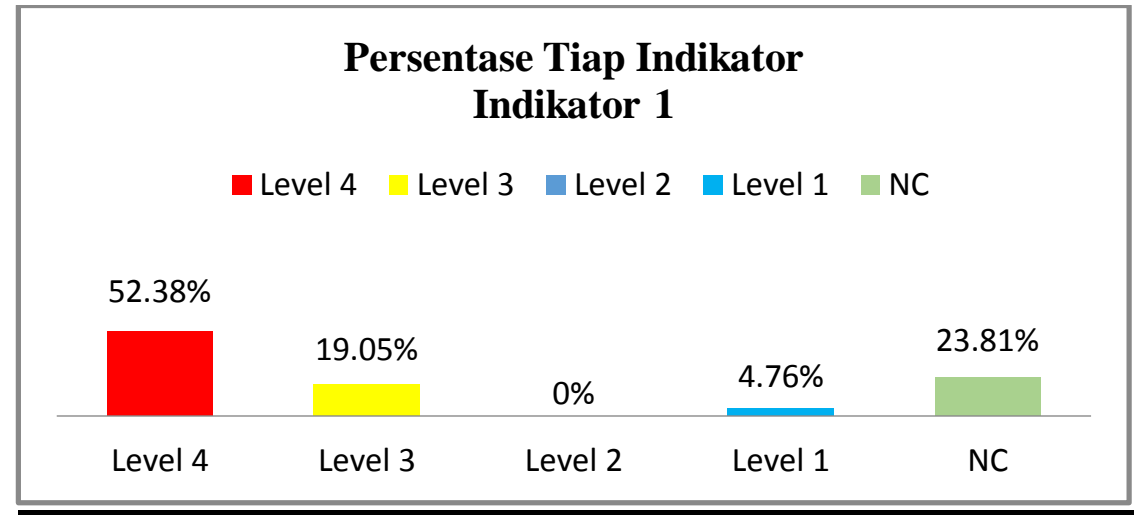

Gambar 1. Diagram Persentase Tiap Level pada Indikator 1

Berdasarkan diagram Gambar 1, mahasiswa yang konsisten menjawab level dapat diketahui persentase kondisi 2 adalah $0 \%$, dan untuk mahasiswa yang mahasiswa yang memahami konsep dengan konsisten menjawab pada level 1 sebesar benar, mengalami miskonsepsi, dan tidak 4,76\%. Sedangkan mahasiswa yang memahami konsep. Mahasiswa yang menjawab tidak konsisten pada tiga butir konsisten menjawab level 4 memiliki soal setara adalah sebesar $23,81 \%$ atau 5 persentase 52,38\% atau sekitar 11 mahasiswa, hal ini menunjukkan bahwa mahasiswa, hal ini menunjukkan bahwa mahasiswa tersebut tidak memahami mahasiswa tersebut telah memahami konsep sehingga dalam menjawab soal konsep dengan benar untuk indikator 1 . Persentase mahasiswa yang konsisten menjawab level 3 sebesar 19,05\%, hal ini menunjukkan 4 mahasiswa mengalami miskonsepsi pada level 3. Persentase kemungkinan dengan cara menebak.

Analisis level tiap butir soal untuk butir soal nomor 1 ditunjukkan pada Gambar 2 berikut.

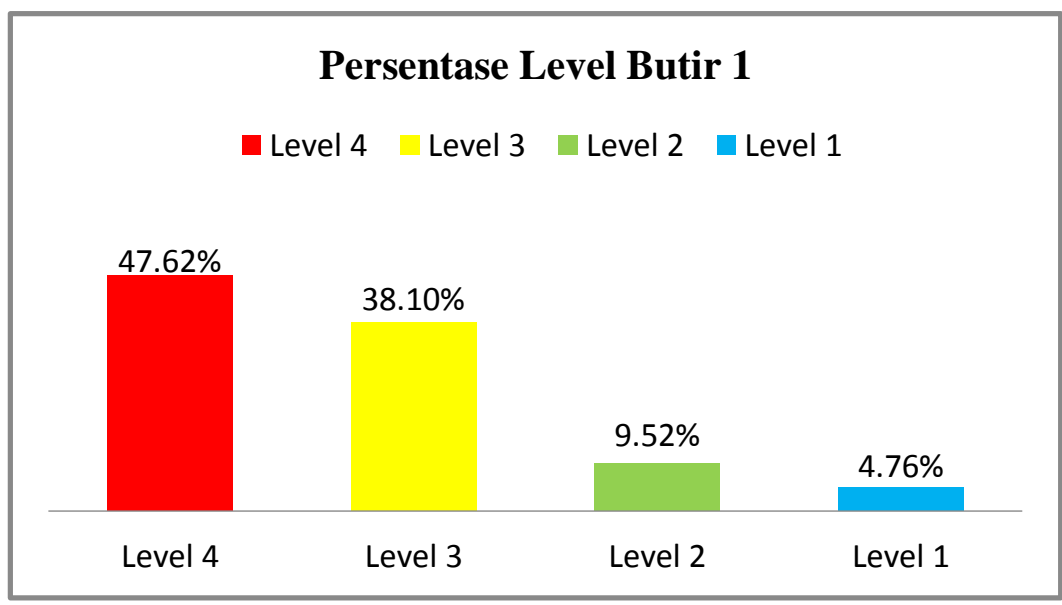

Gambar 2. Diagram Persentase Tiap Level pada Butir Soal Nomor 1 
Berdasarkan diagram pada Gambar 2, pada butir soal nomor 1 ada $47,62 \%$ mahasiswa menjawab level 4; 38,10\% mahasiswa menjawab level $3 ; 9,52 \%$ mahasiswa menjawab level 2 ; dan $4,76 \%$ mahasiswa menjawab level 1. Analisis tiap indikator merupakan pendekatan yang dapat menunjukkan konsistensi jawaban mahasiswa pada indikator tertentu. Sedangkan analisis level tiap butir menampilkan respon mahasiswa yang sesungguhnya. Dosen tinggal mengamati butir-butir yang menunjukkan potensi masalah, yakni butir soal dengan persentase rendah pada level 4.

Analsis profil mahasiswa dapat memberikan umpan balik pada mahasiswa untuk memperbaiki cara belajar mahasiswa berdasarkan kesulitan yang dialami. Berikut disajikan hasil analisis salah satu responden.

Tabel 6. Ringkasan Profil Mahasiswa untuk Responden 1

\begin{tabular}{|l|l|}
\hline \hline Responden 1: & xxxxxxx \\
\hline Saudara perlu meluangkan waktu untuk mempelajari lagi materi ini dan \\
berdiskusi lebih lanjut dengan Dosen. Untuk lebih jelasnya, perhatikan catatan \\
di bawah. \\
Indikator 1: Mahasiswa berpikir bahwa jarak total dalam satu getaran penuh \\
sama dengan simpangan getaran pada saat tertentu \\
Indikator 3: Mahasiswa berpikir bahwa frekuensi sudut lebih besar \\
ditunjukkan pada grafik yang memiliki jumlah gelombang yang lebih rapat \\
Indikator 4: Mahasiswa berpikir bahwa periode percobaan 1 lebih besar \\
daripada percobaan 2 karena pada percobaan 2 diberikan kecepatan awal \\
Indikator 5: Jawaban tidak konsisten pada Indikator ini, perlu dipelajari lagi \\
Indikator 13: Mahasiswa berpikir bahwa energi kinetik benda di posisi \\
simpangan maksimum bernilai maksimum sedangkan bernilai nol di posisi \\
setimbang \\
Indikator 11: Mahasiswa berpikir bahwa ketika dua sistem pegas-massa yang \\
bermassa berbeda berada di posisi yang sama, benda yang bermassa lebih kecil \\
memiliki energi total lebih besar daripada benda yang bermassa lebih besar \\
Indikator 14: Mahasiswa berpikir bahwa sudut awal simpangan yang lebih \\
besar mengakibatkan jarak tempuh semakin besar sehingga periode semakin \\
besar
\end{tabular}

Analisis profil kelas menunjukkan kondisi secara keseluruhan antara mahasiswa yang memahami konsep dan mengalami miskonsepsi. Gambar 3 berikut menyajikan hasil analisis profil kelas. 


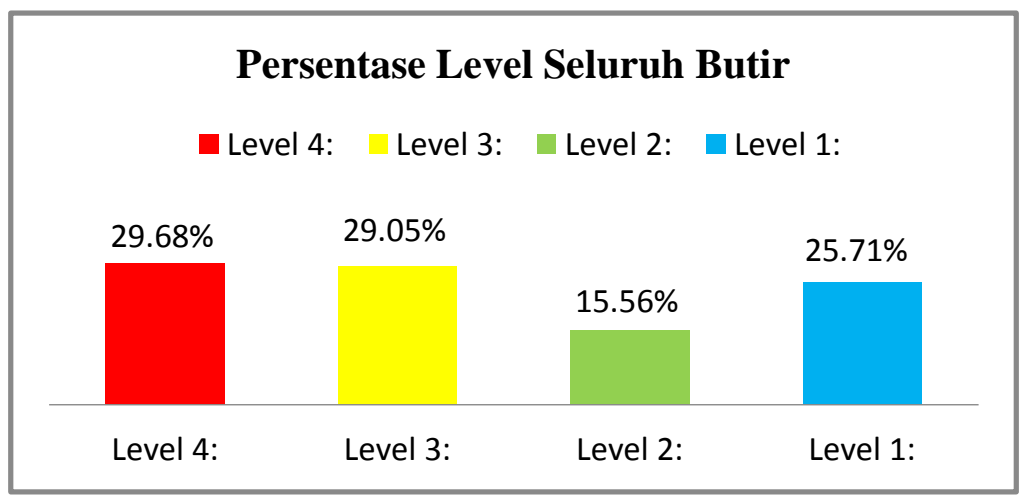

Gambar 3. Diagram Profil Kelas

Gambar 3 menunjukkan bahwa mahasiswa yang menjawab level 4 sebesar 29,68\% ; level 3 sebesar $29,05 \%$; level 2 sebesar $15,56 \%$; dan level 1 sebesar $25,71 \%$. Hal ini menunjukkan bahwa sebagian besar mahasiswa mengalami miskonsepsi baik level 1, 2, ataupun 3 .

Produk yang dikembangkan telah mampu mengidentifikasi karakteristik konsepsi mahasiswa serta dapat membedakan mahasiswa yang memahami konsep dengan benar; mengalami miskonsepsi beserta miskonsepsi yang dialami; dan tidak memahami konsep. Selain itu, hasil analisis mampu memberikan balikan untuk mahasiswa dalam memperbaiki cara belajar dan mempermudah Dosen untuk memberikan remidiasi. Secara keseluruhan, analisis profil kelas menunjukkan bahwa mahasiswa yang memahami konsep dengan benar masih tergolong rendah, yaitu 29,68 $\%$; sedangkan $70,32 \%$ mengalami miskonsepsi.

\section{KESIMPULAN}

Hasil yang dikembangkan berupa instrumen tes pilihan ganda distraktor bermakna untuk

mengidentifikasi karakteristik konsepsi fisika mahasiswa telah berhasil dilakukan. Jumlah soal pada instrumen tes yang dikembangkan adalah 30 butir soal, yang dikembangkan dari 10 indikator. Hasil analisis menyatakan bahwa sebagian besar butir soal tes pilihan ganda yang dikembangkan dinyatakan layak dari segi materi, konstruksi, dan bahasa.

\section{DAFTAR PUSTAKA}

Arifiadi, Nur. 2013. Penggunaan Metode Demonstrasi Berbantuan Flip Chart untuk Meremediasi Miskonsepsi Peserta didik Tentang Getaran di SMP. Jurnal Pendidikan dan Pembelajaran, 2 (11). (Online), (http://jurnal.untan.ac.id/index.php/jpd $\mathrm{pb} /$ article/view/3790/3795.html), diakses 08 Desember 2013.

Arikunto, S. 2009. Dasar-dasar Evaluasi Pendidikan (edisi revisi). Jakarta: Bumi Aksara. 
Berg, dkk. 1991. Miskonsepsi fisika dan Remidiasi. Salatiga: Universitas Satya Wacana.

Beverley, Bell Formative, 2002. Formative Assessment and Science Education.

Bilgin, Ibrahim. 2009. "The Effects of Guided Inquiry Instruction Incorporating a Cooperative Learning Approach on University Students ' Achievement of Acid and Bases Concepts and Attitude toward Guided Inquiry Instruction” 4 (10): 1038-46.

Creswell, John W. 2010. "Research Design." Journal of Educational Technology and Society.

Kácovský, P. 2013. "Students ' Alternative Conceptions in Thermodynamics," 100-103.

Kang, Hunsik, Lawrence C Scharmann, Sukjin Kang, and Taehee Noh. 2010. "Cognitive Conflict and Situational Interest as Factors Influencing Conceptual Change" 5 (4): 383-405.

Kusairi, S. 2014. Assesment For Learning Berbasis Teknologi Web. Malang: UM Press

Melissa S. Anderson , Marta A. Shaw, Nicholas H. Steneck , Erin Konkle, and Takehito Kamata. 2013. Research Integrity and Misconduct in the Academic Profession. Edited by Michael B. Paulsen. XXVIII. The University of Iowa.

Nline, O, P Rofessional D Evelopment, and Carl J Wenning. 2008. "Conceptions in Science" 5 (1).

Nottis, Katharyn E K, Michael J Prince, and Margot A Vigeant. 2010. "Building an Understanding of Heat Transfer Concepts in Undergraduate Chemical Engineering Courses *" 7 (2): $1-9$.

Richey, Rita C, James D Klein, and Wayne A Nelson. 2011. "Developmental Research: Studies Of Instructional Design And Development."

Rusilowati, Ani, and Ahmad Sopyan. 2011. "Pengembangan Concept-Mapping Assessment" 7: 13-16.

Stedman, Nicole L P, and Brittany L Adams. 2012. "Identifying Faculty' S Knowledge of Critical Thinking Concepts and Perceptions of Critical Thinking Instruction in Higher Education 1," no. June: 9-15.

Tanahoung, Choksin, Ratchapak Chitaree, and Chernchok Soankwan. 2010. "Probing Thai Freshmen Science Students ' Conceptions of Heat and Temperature Using Open-Ended Questions : A Case Study" 2 (2): $82-$ 94.

Taylor, Joseph A, Thomas M Dana, Ingrid Novodvorsky, Debra Tomanek, Carl J Wenning, and Jpteo Editor-in-chief. 2002. “J P T E O” 1 (2).

Wells, Gordon. 1994. Learning and Teaching "Scientific Concepts": Vygotsky's Ideas Revisited. Vygotstky and the Human Sciences.

Wijaya, Mujiman Hendri,. Suratno, dan Aminuddin HP. 2013. Pengembangan Tes diagnostik Mata Pelajaran IPA SMP. Jurnal Penelitian dan Evaluasi Pendidikan, 17 (1): 19-36. 